\title{
UPAYA MENINGKATKAN KETERAMPILAN MENULIS TEKS DESKRIPSI DENGAN MEDIA VISUAL PADA SISWA KELAS VII C SMPN 30 SURABAYA
}

\author{
Imayah $^{1}$, Windi Setiawan ${ }^{2}$, dan Edy Widayat ${ }^{3}$ \\ Universitas Dr. Soetomo Surabaya \\ 1Email: 1 imayah@unitomo.ac.id, ${ }^{2}$ windi.s@,unitomo.ac.id, ${ }^{3}$ edy.widayat@unitomo.ac.id
}

\begin{abstract}
Informasi Artikel Abstrak

Kata kunci:

Menulis

Teks Deskripsi

Media Visual

Diterima: $10-09-2020$

Disetujui: 01-10-2020

Dipubikasikan: 26-10-2020

Dari hasil refleksi awal dapat diketahui kemampuan dalam menulis teks deskripsi peran siswa kelas VII C SMP Negeri 30 Surabaya rendah. Teridentifikasi beberapa masalah yang berkaitan dengan kemampuan siswa dalam menulis teks deskripsi, yaitu dari segi penggunaan Bahasa (EYD), diksi, kreatifitas mengarang dan pendeskripsian media gambar. Untuk mengatasi masalah tersebut peneliti memberikan pembelajaran dengan memanfaatkan fasilitas media visual. Penelitian ini adalah penelitian tindakan kelas. Subjek penelitian ini adalah siswa kelas VII C SMP Negeri 30 Surabaya semester ganjil tahun akademik 2018/2019, yang berlokasi di Jl. Medokan Semampir 119 Surabaya. Berdasarkan hasil penelitian, dapat disimpulkan bahwa media visual dapat meningkatkan kemampuan menulis teks deskripsi siswa kelas VII C SMP Negeri 30 Surabaya. Hal ini dapat dilihat pada tiga aspek yaitu 1) Aktivitas guru pada siklus 1 yaitu $80 \%$ meningkat menjadi $100 \%$ pada siklus 2; 2) Presentase aktivitas siswa siklus 1 yaitu $75,38 \%$, sedangkan pada siklus 2 mengalami peningkatan yaitu $100 \%$; 3) Hasil tes kemampuan siswa dalam menulis teks deskripsi pada siklus I, 25 siswa dapat mencapai ketuntasan klasikal dengan persentase sebesar 68,87\%. Sedangkan pada siklus II mengalami peningkatan yaitu seluruh siswa dengan jumlah 40 siswa mencapai ketuntasan klasikal dengan persentase 100\%.
\end{abstract}

\section{PENDAHULUAN}

Bahasa Indonesia didalam proses pembelajaran merupakan salah satu mata pelajaran wajib yang diajarkan pada tingkat pendidikan dasar, menengah pertama maupun menengah atas, hingga pada jenjang perguruan tinggi. Kompetensi berbahasa sendiri terdiri dari empat aspek berbahasa, yaitu keterampilan menyimak, keterampilan berbicara, keterampilan membaca, dan yang terakhir adalah keterampilan menulis.

Dari keempat keterampilan berbahasa tersebut, keterampilan menulis sering sekali menjadi sorotan. Karena kurangnya motivasi dan penguasaan siswa dalam keterampilan menulis. Effendi (2008:327) berpendapat bahwa 
menulis merupakan suatu aktivitas komunikasi bahasa satu sama lain yang menggunakan bahasa sebagai mediumnya.

Keraf (1982:93) arti deskripsi adalah suatu wacana yang digunakan untuk menyampaikan hal atau objek pembicaraan sehingga para pembaca seperti melihat sendiri objek tersebut secara langsung. Didalam deskripsi penulis memindahkan kesan-kesannya, hasil penggambaran, perasaan, penyampaian sifat, dan rincian wujud yang ditemukan pada objek.

Daryanto (1993:27) media visual artinya semua alat peraga yang digunakan dalam proses belajar yang bisa dinikmati lewat panca-indramata. Media visual (gambar atau perumpamaan) memegang peran yang sangat penting dalam proses belajar mengajar. Pentingnya media visual karena media visual dapat memperlancar pemahaman dan memperkuat ingatan. Visual dapat pula menimbulkan minat siswa dan dapat menghubungkan antara isi materi pelajaran dengan dunia nyata.

Pembelajaran menulis selama ini di sekolah lebih mengutamakan hasil daripada proses. Siswa dituntut untuk menghasilkan sebuah tulisan tanpa melalui proses menulis. Tahapan-tahapan menulis di abaikan, sehingga siswa melakukan kegiatan menulis sesuai dengan tuntutan, yakni hanya menyelesaikan tulisan, Anonim (2009).

Terkait dengan mata pelajaran Bahasa Indonesia di SMPN 30 Surabaya pada siswa kelas VII C semester gasal, yaitu dengan tema mendeskripsikan suatu objek melalui kegiatan menulis sesuai dengan penggunaan bahasa, diksi, dan tingkat kreatifitas ini siswa diharapkan dapat menulis melalui teks deskripsi dengan media visual.

Berdasarkan hasil observasi di lapangan dengan guru mata pelajaran Bahasa Indonesia di SMPN 30 Surabaya, sebagai indikator belum optimalnya kemampuan siswa menulis, ditunjukkan dari hasil tulisan siswa yang belum biasa mencapai pencapaian KKM. Beberapa kelemahan yang tampak dari hasil pekerjaan siswa adalah sebagai berikut. Pertama, penggunaan Bahasa yang dihasilkan belum baik (tidak jelas) jadi siswa belum mampu membuat paragraf yang baik. Kedua, kalimat yang digunakan tidak efektif jadi sebagian besar siswa menulis kalimat yang bertele-tele, Ketiga, siswa belum meampu berkreasi luas dalam mengarang cerita deskripsi.

Berdasarkan latar belakang permasalahan dan pemikiran tersebut, Rumusan masalah yang diperoleh adalah menawarkan solusi atau alternatif pemecahan masalah yang dipilih dalam upaya meningkatkan keterampilan menulis pada siswa kelas VIIC di SMP NEGERI 30 Surabaya ini adalah dengan penelitian tindakan kelas (Classroom Action Research) melalui kegiatan menulis teks deskripsi dengan media visual. Dipilihnya melalui teks deskripsi dengan media visual karena media pembelajaran tersebut dipandang mampu dalam mengembangkan segala imajinasi yang dimiliki siswa, kemudian bebas dalam menuangkan ide pikirannya ke dalam bentuk tulisan. Siswa disini dirangsang untuk mengembangkan masing-masing kemampuan berfikir, kreativitas dan mengeluarkan ekspresinya. Jadi masalah dalam penelitian ini dapat dirumuskan sebagai berikut, “Apakah penerapan media visual dapat meningkatkan keterampilan menulis teks deskripsi pada siswa kelas VII 
C SMPN 30 Surabaya?”. Tujuan dalam penelitian ini adalah meningkatkan pembelajaran keterampilan menulis melalui teks deskripsi dengan media visual pada siswa kelas VII C SMPN 30 Surabaya. Sebagai indikator keberhasilan pemecahan masalah adalah mempermudah siswa dalam terampil Menulis terutama dalam menulis deskripsi.

\section{METODE}

Subjek dalam penelitian ini adalah siswa Kelas VII C SMPN 30 Surabaya yang seluruhnya berjumlah 40 siswa. Penelitian ini dilaksanakan di SMP Negeri 30 Surabaya. Lokasi SMP Negeri 30 terletak di Jl. Medokan Semampir 119 Surabaya. Dalam Penelitian Tindakan Kelas dilakukan dengan melalui siklus. Pelaksanaan tiap siklus dilakukan empat tahap yang meliputi, 1) perencanaan, 2) pelaksanaan, 3) evaluasi/observasi, dan 4) refleksi.

\section{Perencanaan}

Langkah langkah perencanaan adalah sebagai berikut.

- Menemukan masalah penelitian yang ada di lapangan. Pada fase ini dilakukan melalui diskusi dengan guru kelas, maupun melalui observasi di dalam kelas. Dengan mencatat hal-hal serta permasalahan pembelajaran yang ada di kelas VII C SMPN 30 Surabaya.

- Menjelaskan pembelajaran terkait menulis teks deskripsi menggunakan media gambar.

- Merencanakan langkah -langkah proses pembelajaran, yaitu pembelajaran mulai dari siklus awal. Namun perencanaan yang dibuat masih bersifat fleksibel dan terbuka terhadap perubahan dalam pelaksanaannya.

- Merancang instrumen sebagai pedoman observasi dalam tata pelaksanaan pembelajaran menulis teks deskripsi.

\section{Tindakan dan Observasi/ Evaluasi}

- Tindakan (Pelaksanaan)

Dalam tahap pelaksanaan tindakan, telah disepakati dengan Guru mata pelajaran bahasa indonesia sebagai pelaksana rencana tindakan yang telah disusun rapi, sedangkan Imayah dengan Windi Setiawan akan bertindak sebagai pengamat dalam kelas. Selanjutnya pelaksana melaksanakan tindakan pelaksanaan dalam situasi praktik pembelajaran nyata di dalam kelas. Pelaksana disini diharapkan benar-benar mempraktikkan belajar-mengajar secara langsung sesuai dengan skenario yang sudah disusun.

- Observasi dan Evaluasi

Kegiatan pengamatan dan penilaian (observasi-evaluasi dilakukan oleh peneliti dan guru bersamaan dengan pelaksanaan tindakan yang telah direncanakan. Observasi dilakukan peneliti terhadap aktivitas siswa dan guru 
yang berkaitan dengan aktivitas siswa dalam menulis teks deskripsi, dan menerapkan media visual. Observasi tersebut dilakukan dengan menggunakan lembar observasi dan lembar penilaian untuk pedoman penilaian.

\section{Refleksi}

Pada tahap refleksi, data yang diperoleh dari hasil pengamatan tentang aktivitas guru dalam mengelola kelas dan kemampuan siswa dalam menulis teks deskripsi selama pelaksanaan tindakan diolah dan dianalisis. Pada tahap refleksi, jika pelaksanaan pada siklus I sudah tuntas tidak akan dibutuhkan lagi siklus berikutnya. Sebaliknya jika pada siklus I masih belum tuntas maka akan dilanjutkan pada siklus berikutnya.

Teknik pengumpulan data yang digunakan penelitian ini adalah menggunakan tes tulis yang dapat mengukur keterampilan menulis teks deskripsi dengan menggunakan media gambar berupa tugas menulis deskripsi dan observasi yang bertujuan untuk mengetahui suasana kegiatan yang dilaksanakan saat pembelajaran berlangsung baik itu di dalam kelas maupun saat berada di luar kelas.

Data ini dianalisis dengan deskriptif kuantitatif yaitu dengan mencari rerata. Peningkatan kemampuan menulis teks deskripsi dari siklus I dan siklus selanjutnya dihitung dengan rumus sebagai berikut.

- Analisis Data Hasil Observasi

Aktivitas Guru

Dari aktivitas guru yang muncul dapat dihitung dengan rumus sebagai berikut:

Aktivitas Guru $=\underline{\text { Aktivitas yang muncul }} \times 100 \%$

Aktivitas Siswa

Aktivitas siswa yang muncul dirumuskan sebagai berikut:

Akitvitas Siswa $=\underline{\text { Aktivitas yang muncul }} \times 100 \%$

- Analisis Data Hasil Tes

Untuk nilai KKM individual yaitu siswa harus mendapatkan nilai 75 ke atas.

Skor Individual $=\underline{\text { Nilai yang diperoleh }} \times 100 \%$

Untuk KKM klasikal yaitu 85\% siswa yang tuntas

Ketuntasan Klasikal $\equiv$ Jumlah siswa tuntas $\times 100 \%$

\section{HASIL DAN PEMBAHASAN}

\section{Hasil Penelitian}

Pada tahap ini memaparkan hasil penelitian yang telah dirumuskan pada RPP (rencana pelaksanaan pembelajaran), lembar pengamatan kinerja guru dan siswa, hasil belajar siswa. Pada siklus I diketahui bahwa 
selama pelaksanaan tindakan siklus I dapat dikemukakan bahwa guru belum sepenuhnya melaksanakan tindakan seperti yang telah direncanakan dalam RPP. Guru masih belum mampu menjelaskan tujuan pembelajaran yang akan dilaksanakan dan belum melakukan evaluasi sesuai dengan yang sudah direncanakan. Sedangkan beberapa aktivitas yang belum dilakukan oleh siswa secara maksimal pada siklus I yaitu 1) siswa belum bisa menulis teks deskripsi dengan media visual, 2) siswa belum merasa media visual sangat efektif dalam membantu pembelajaran menulis teks deskripsi, 3)siswa belum mampu menulis Tks deskripsi dengan baik dan sempurna. Pada tindakan siklus I diketahui siswa yang belum mencapai KKM sebanyak 15 siswa. Sedangkan yang sudah mencapai KKM sebanyak 25 siswa.

Pada siklus II dapat dikemukakan bahwa guru sudah melaksanakan tindakan seperti yang direncanakan dalam RPP. Sedangkan siswa mulai memberikan respon positif terhadap penggunaan media visual dan siswa juga antusias dalam mengikuti pembelajaran ketika proses menulis teks deskripsi. Pada siklus II diketahui siswa yang belum mencapai KKM tidak ada. Sedangkan yang sudah mencapai KKM sebanyak 40 siswa. Sehingga dari siklus I ke siklus II mengalami peningkatan.

\section{Pembahasan}

Hasil dari penelitian peningkatan kemampuan menulis teks deskripsi siswa kelas VII C melalui media visual dapat diperoleh sebagai berikut.

- Observasi Aktivitas Guru

Hasil observasi aktivitas guru pada siklus I yaitu empat aktivitas sudah dilaksanakan dengan persentase $80 \%$. Terdapat satu aktivitas guru yang belum dilaksanakan pada siklus I yaitu yaitu guru tidak memberikan evaluasi. Hasil observasi pada siklus II mengalami peningkatan. Terdapat lima atau semua aktivitas yang sudah dilaksanakan dengan persentase $100 \%$.

\section{- Observasi Aktivitas Siswa}

Hasil observasi aktivitas siswa pada siklus I yaitu 75,38\%. Terdapat beberapa aktivitas yang belum dilakukan oleh siswa secara maksimal yaitu a) siswa masih kurang antusias dalam mengikuti pembelajaran menulis teks deskripsi; b) siswa tidak melakukan tanya jawab tentang materi yang disampaikan guru; c) siswa tidak merefleksi materi pelajaran. Hasil observasi aktivitas siswa pada siklus II sudah mengalami peningkatan yaitu meningkat dengan persentase $100 \%$. Hal ini dapat dilihat pada aspek yang belum tuntas pada siklus I yaitu a) aktivitas siswa bertanya jawab tentang materi yang disampaikan oleh guru; b) siswa merefleksi materi pelajaran; dan c) siswa antusias dalam mengikuti pembelajaran menulis teks deskriptif sudah terpenuhi.

- Hasil Tes Kemampuan Siswa 
Setelah diberi tindakan dengan memberikan adanya media visual yaitu dengan gambar pada siklus I menunjukkan adanya peningkatan kemampuan dalam menulis teks deskripsi. Dari hasil siklus 1 dapat diketahui presentase kemampuan siswa dalam menulis teks deskripsi dari segi penggunaan bahasa (EYD) 18,55\% dengan kriteria baik. Presentase kemampuan siswa dalam menulis teks deskripsi dari segi penggunaan diksi 20,56\% dengan kriteria yang baik. Presentase kemampuan siswa dalam menulis teks deskripsi dari segi kreativitas mengarang 18,15\% dengan kriteria cukup. Presentase kemampuan siswa dalam menulis teks deskripsi dari segi pendeskripsian terkait sebuah media gambar / visual sebesar 18,35\% dengan kriteria cukup Skor presentase skor komulatif seluruh aspek/indikator mencapai 76,80\% dengan kriteria baik. Jadi presentase ketuntasan siklus I yaitu $68,87 \%$

Hasil siklus II juga menunjukkan adanya peningkatan baik per aspek indikatornya maupun secara kumulatif. Dilihat dari hasil per aspek indikatornya dapat diketahui presentase kemampuan siswa dalam menulis teks deskripsi penggunaan bahasa (EYD) sebesar 19,44\% dengan kriteria baik. presentase kemampuan siswa menulis teks deskripsi segi penggunaan diksi sebesar 22,57\% dengan kriteria baik. presentase menulis teks deskripsi kreativitas mengarang sebesar 21,22\% dengan kriteria baik. presentase mengimprovisasi bermain peran dari segi pendeskripsian sebuah media gambar/visual sebesar 19,56\% dengan kriteria baik. presentase skor 5 kumulatif seluruh aspek atau indikator mencapai 80,88\% dengan kriteria baik. Jadi presentase ketuntasan siklus II yaitu meningkat menjadi 100\%. Dapat disimpulkan hasil tes kemampuan siswa pada siklus I ke siklus II mengalami peningkatan dan diartikan TUNTAS. Kesulitan-kesulitan siswa pada siklus I dapat diatasi pada siklus II. Hal ini dibuktikan dengan presentase ketuntasan siklus I yaitu $68,87 \%$ dan ketuntasan siswa meningkat menjadi $100 \%$ pada siklus II. Berdasarkan data tersebut, menunjukkan bahwa menulis teks deskripsi siswa kelas VII C SMP Negeri 30 Surabaya dengan memanfaatkan media visual dapat meningkat.

\section{KESIMPULAN}

Berdasarkan hasil penelitian dan pembahasan dapat disimpulkan bahwa penggunaan media gambar dapat meningkatkan keterampilan menulis teks deskripsi pada siswa kelas VII C SMP Negeri Surabaya.

\section{DAFTAR PUSTAKA}

Arikunto, Suharsimi, dkk. 2010. Penelitian Tindakan Kelas. Jakarta: PT. Bumi Aksara.

Anonim Suparno dan Mohamad Yunus. (2008). Keterampilan Dasar Menulis. Jakarta: Universitas Terbuka.

Burhan Nurgiyantoro. (2009). Penilaian Pembelajaran Bahasa dan Sastra Indonesia.Yogyakarta: BPFE

Daryanto, Mukayat D., 2002. Penulisan Karangan Ilmiah Edisi Revisi. Jakarta:Akademia Pressindo.

Keraf, Gorys. 1984. Komposisi: Sebuah Pengantar Kemahiran Bahasa. Ende- Flores: Nusa Indah.

Mulyasa, H. E. 2011. Praktik Penelitian Tindakan Kelas. Bandung: PT. Remaja Rosdakarya.

Nurgiyantoro, Burhan. 2001. Penilaian dalam Pengajaran Bahasa dan Sastra (Edisi ke- 3). Yogyakarta: BPFEYogyakarta. 
Rahadi, Aristo. 2003. Media Pembelajaran. Jakarta: Departemen Pendidikan Nasional.

Tarigan, Henri Guntur. 2013. Menulis Sebagai Suatu Keterampilan Berbahasa. Bandung: Angkasa Bandung.

Trianto. 2012. Panduan Lengkap Penelitian Tindakan Kelas. Jakarta: Prestasi Pustakaraya. 